\title{
Application of coatings made by plasma spray and PVD methods for protecting graphite molds
}

\author{
Powłoki ochronne nakładane metodami natrysku plazmowego \\ oraz PVD na grafitowe krystalizatory przemysłowe
}

\begin{abstract}
The results of our research on the application of coatings for protecting industrial casting molds are presented. Tests were carried out on graphite molds with deposited $\mathrm{Al}_{2} \mathrm{O}_{3}$ coatings containing the addition of glassy carbon and with W/Zr/DLC coatings, both examined after the process of pouring molds with molten aluminum bronze. The coatings were applied by two different methods; i.e., plasma spraying in the case of $\mathrm{Al}_{2} \mathrm{O}_{3}+$ glassy carbon coating and PVD in the case of W/Zr/DLC coating. Reference tests were also conducted on graphite molds without coating. The use of protective coatings on graphite molds seems to be an effective solution. Studies have shown that coatings have good resistance during the casting process. The liquid metal sticking to the surface did not penetrate deep inside the graphite mold. The use of coating technology reduces the amount of downtime necessary to replace worn molds and increases the efficiency of the casting process.
\end{abstract}

Keywords: graphite molds, protective coatings, plasma spraying, PVD

\section{Streszczenie}

W pracy przedstawiono wyniki badań dotyczące zastosowania powłok do ochrony grafitowych krystalizatorów przemysłowych. Badaniom poddano krystalizator grafitowy bez naniesionej powłoki, jak i z powłoką $\mathrm{Al}_{2} \mathrm{O}_{3}$ z dodatkiem węgla szklistego otrzymaną metodą natrysku plazmowego oraz krystalizator z powłoką W/Zr/DLC otrzymaną metodą PVD. Przeprowadzone badania dowodzą, że zastosowanie powłok w celu ochrony powierzchni krystalizatorów może być skutecznym rozwiązaniem. Badania wykazały, że zarówno powłoki ceramiczne $\mathrm{Al}_{2} \mathrm{O}_{3}+$ węgiel szklisty, jak i powłoka W/Zr-DLC zapewniają ochronę krystalizatora w trakcie kontaktu z ciekłym medium. Badania strukturalne oraz analiza składu chemicznego zostały przeprowadzane z zastosowaniem skaningowej mikroskopii elektronowej (HITACHI SU-70).

Słowa kluczowe: krystalizatory grafitowe, powłoki ochronne, natrysk plazmowy, PVD

Ilona Nejman Ph.D. Eng., Maria Richert Ph.D. D.Sc. Eng., Paulina Zawadzka M.Sc. Eng.: AGH University of Science and Technology, Faculty of Non-Ferrous Metals, Department of Materials Science and Non-Ferrous Metals Engineering, Krakow, Poland; inejman@agh.edu.pl 


\section{Introduction}

The use of protective coatings in many industrial sectors allows for more-complex development of surface engineering techniques. Studies show that protective coatings are used in many sectors of the industry, depending on the imposed requirements [1-4]. The most vulnerable to damaging factors are machine parts and devices, particularly those designed for long-term use. The surface of graphite molds used for casting copper and its alloys can be modified with protective coatings to extend the service life and improve the efficiency of the casting process. Graphite is a heterogeneous material, and as such has a number of pores and voids. During casting, these discontinuities allow the liquid medium to penetrate into the mold interior. After melting about 12 tons of the cast metal, the graphite mold has to be replaced to avoid further deterioration of the melt surface $[5,6]$. The use of protective coatings can be a solution to the problem. Coatings that prevent degradation of the graphite surface are prepared by various surface engineering methods, such as thermal spray (High Velocity Oxygen Fuel - HVOF), plasma spray (PS), plasma-assisted physical vapor deposition in a vacuum (PA PVD), and plasmaassisted chemical vapor deposition in a vacuum (PA CVD). In most cases, the methods for the preparation of coatings are based on the use of a plasma phase.

Selection of the coating material depends on the future application of the component. In the case of the foundry industry, coatings are expected to meet certain criteria, such as null wettability by the metal cast, smoothness, and resistance to high temperatures. The use of hybrid coatings that combine several layers appears to be a reasonable option. The methods listed above allow for the production of coatings characterized by properties dedicated to a particular class of applications $[7,8]$.

Aluminum oxide is used for the protective coatings due to a number of valuable properties, to mention only great high hardness and abrasive wear resistance. Aluminum oxide coatings have good insulating properties and are stable at high temperatures $[9,10]$. Unfortunately, coatings obtained by plasma spraying are characterized by high levels of porosity. To confer adequate smoothness to the surface layer, an additional layer of glassy carbon is applied; this eliminates the problem of roughness and/or porosity, eliminating also the risk that the surface might be wetted by metals such as $\mathrm{Al}, \mathrm{Cu}, \mathrm{Zn}, \mathrm{Ag}$, or $\mathrm{Sn}[11,12]$. Tungsten is a chemical element characterized by high hardness and a very high melting point $\left(3600^{\circ} \mathrm{C}\right)$. Often in surface engineering, the protective coatings are made of tungsten carbide, mainly due to its specific properties [13, 14]. Hybrid coatings combined with layers of W and Zr-DLC are used to improve the coating properties, surface smoothness and tightness included. The use of diamond-like coatings (which is a novel solution in the field of surface engineering, offering high thermal resistance, good conductivity, and high hardness) has considerably improved the quality of the tested materials $[15,16]$.

The main aim of this study was to disclose the results of our research on the application of coatings for protecting industrial molds. Tests and studies included graph- 
ite molds without any coating, with an $\mathrm{Al}_{2} \mathrm{O}_{3}$ coating containing the addition of glassy carbon deposited by plasma spraying, and with a W/Zr + DLC coating produced by PVD.

\section{Experimental procedure}

Samples for testing were deposited by thermal spraying in company Plasma System SA Siemianowice Śląskie using an MIM40 device. The applied process parameters are summarized in Tables 1 and 2.

Table 1. Parameters of the plasma spray process

\begin{tabular}{|c|c|c|c|c|c|}
\hline \multicolumn{2}{|c|}{ Plasma Spraying } \\
\hline Material & $\begin{array}{c}\text { Spraying distance } \\
{[\mathbf{m m}]}\end{array}$ & $\boldsymbol{U}[\mathbf{V}]$ & $\boldsymbol{I}[\mathrm{A}]$ & \multicolumn{2}{|c|}{ Gases [I/h] } \\
\cline { 4 - 6 } & 80 & 58 & 450 & $\mathbf{A r}$ & $\mathbf{H}_{\mathbf{2}}$ \\
\hline $\mathrm{Al}_{2} \mathrm{O}_{3}$ & & & 2500 & 160 \\
\hline
\end{tabular}

Table 2. Parameters of the EB PVD process

\begin{tabular}{|c|c|c|c|c|}
\hline Material & $\begin{array}{c}\text { Pressure in the } \\
\text { chamber } \boldsymbol{p}_{\boldsymbol{k}}[\mathrm{mbar}]\end{array}$ & Beam current $\boldsymbol{I}_{\boldsymbol{w}}[\mathbf{A}]$ & Temperature $\left[{ }^{\circ} \mathbf{C}\right]$ & Time [min] \\
\hline $\mathrm{W}$ & $5 \cdot 10^{-5}$ & 0.15 & $<200$ & 45 \\
\hline
\end{tabular}

The layer of glassy carbon was produced on the surface of the $\mathrm{Al}_{2} \mathrm{O}_{3}$ coating by soaking in a 0.1 mole of 4-toluenesulphonic acid solution in enanol. The next step was annealing it at $90^{\circ} \mathrm{C}$ for $1 \mathrm{~h}$ and soaking it in a solution of acid mixed with odorless ethylene at a ratio of $1 / 20$. Then followed annealing at $120^{\circ} \mathrm{C}$ for $1 \mathrm{~h}$ and heat treatment in a protective atmosphere of argon. Heating at $200^{\circ} \mathrm{C}$ holding at $1000^{\circ} \mathrm{C}$ for $2 \mathrm{~h}$, and furnace cooling ended the process.

Sample coatings produced by PVD methods for further studies were prepared under industrial conditions at the Institute for Sustainable Technologies - National Research Institute (ITeE-PIB) in Radom, Poland. The coatings were deposited by two different methods: Electron Beam Physical Vapor Deposition EB PVD and Cathodic Arc Deposition Arc PVD. Process parameters are summarized in Table 3.

Table 3. Parameters of the ARC PVD process

\begin{tabular}{|c|c|c|c|c|c|}
\hline Sample & $\begin{array}{l}\text { Pressure in the } \\
\text { chamber } p_{k} \\
\text { [mbar] }\end{array}$ & $\begin{array}{c}\text { Gases } \\
\text { [ml/min] } \\
\mathrm{pC}_{2} \mathrm{H}_{2}\end{array}$ & $\begin{array}{c}\text { Current } \\
\text { source } I_{z} \\
{[A]}\end{array}$ & $\begin{array}{c}\text { Temperature } \\
{\left[{ }^{\circ} \mathrm{C}\right]}\end{array}$ & $\begin{array}{l}\text { Time } \\
\text { [min] }\end{array}$ \\
\hline $\mathrm{Zr}+\mathrm{DLC}$ & $7.4 \cdot 10^{-4}$ & 45 & 90 & 300 & 90 \\
\hline
\end{tabular}


Trials of the semi-continuous casting process were carried out under laboratory conditions on a test stand.

Figure 1 shows the test mold surface after the process of semi-continuous casting using $24.5 \mathrm{~kg}$ of BA 1032 bronze.

a)

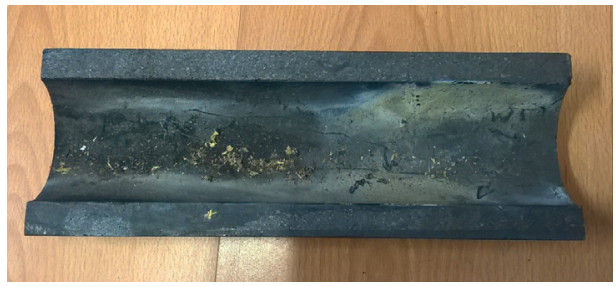

b)

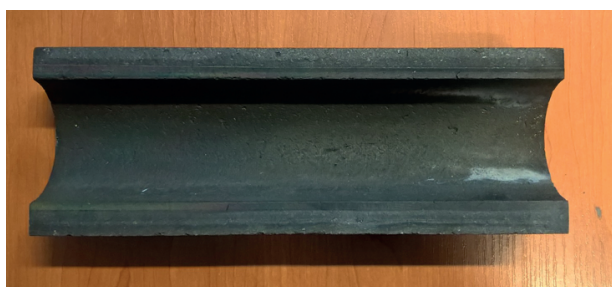

c)

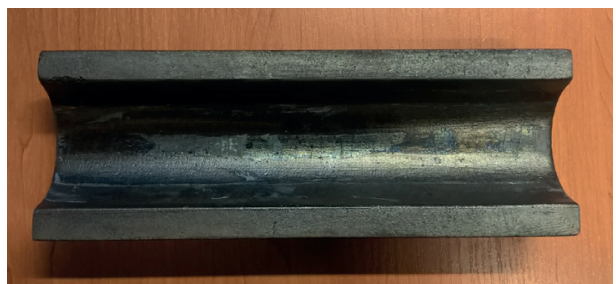

Fig. 1. The appearance of the graphite mold surface after the semi-continuous casting process: a) mold without coating; b) W/Zr-DLC coating; c) $\mathrm{Al}_{2} \mathrm{O}_{3}+$ glassy carbon coating

The structures of all of the samples were examined under a Hitachi SU-70 Scanning Electron Microscope. Samples for examinations by light microscopy were polished mechanically using a Struers equipment and technique. They were ground first and then polished with diamond pastes and OPS suspension.

\section{Results and discussions}

Figure 2 shows the structure of a mold without any protective coating after the semicontinuous casting process. The structure is heterogeneous. Visible pores and cracks facilitate the liquid metal penetration into the graphite. A chemical analysis allowed us to identify the presence of elements such as $\mathrm{Cu}, \mathrm{Al}, \mathrm{Sn}$, Fe, or $\mathrm{O}$ inside the uncoated mold (Fig. 3). 
a)

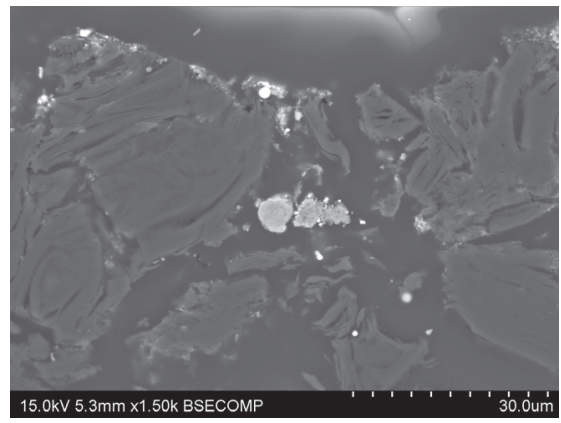

b)

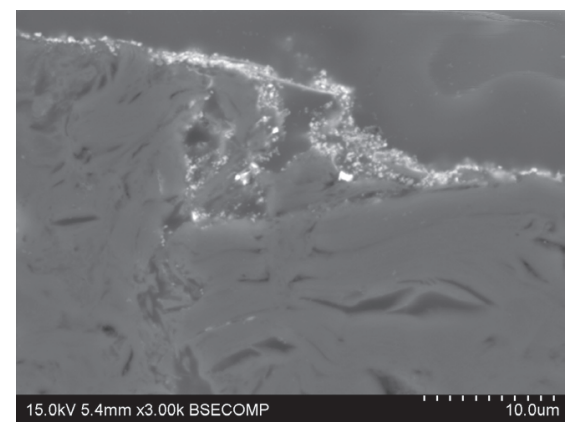

Fig. 2. The microstructure of a graphite mold without coating: a) cross-section; b) upper surface in top view (SEM)

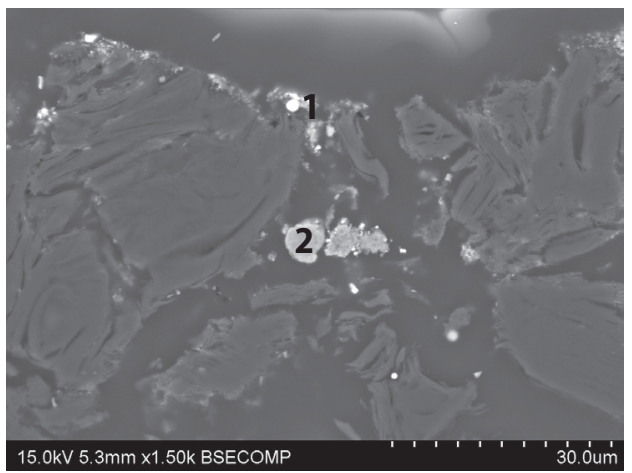

\begin{tabular}{|c|c|c|c|c|c|c|c|c|}
\hline No. & $\mathbf{C}$ & $\mathbf{0}$ & $\mathbf{A l}$ & $\mathbf{S}$ & $\mathbf{N i}$ & $\mathbf{F e}$ & $\mathbf{C u}$ & Sn \\
\hline 1 & 66.63 & 22.13 & 0.05 & 0.47 & 1.70 & 8.61 & 0.31 & 0.11 \\
\hline 2 & 60.68 & 28.38 & 0.19 & 0.21 & 8.81 & 1.12 & 0.49 & 0.12 \\
\hline
\end{tabular}

Fig. 3. Chemical analysis of a graphite mold without coating -cross-section

The structure of the W/Zr DLC coating deposited on a graphite mold is shown in Figure 4. Well visible is the outer $\mathrm{Zr}+\mathrm{DLC}$ layer (about $1 \mu \mathrm{m}$ thick) and the intermediate layer of tungsten (with an average thickness of about $7 \mu \mathrm{m}$ ). The coating has a homogenous structure, is compact, and closely adheres to the substrate. Chemical analysis displayed in the form of maps of the distribution of elements shows in top view the surfaces after the casting process of BA1032 bronze. Visible are small fragments of the sticking metal. Elements such as $\mathrm{Zr}, \mathrm{W}, \mathrm{Cu}, \mathrm{O}$, and $\mathrm{C}$ have been identified (Fig. 5). The coating is tight; thus, providing effective protection for the graphite mold. 
a)

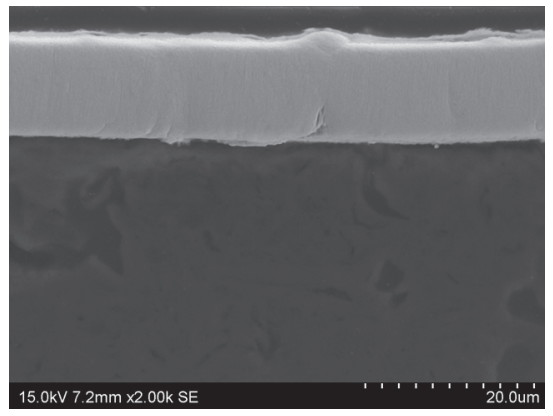

b)

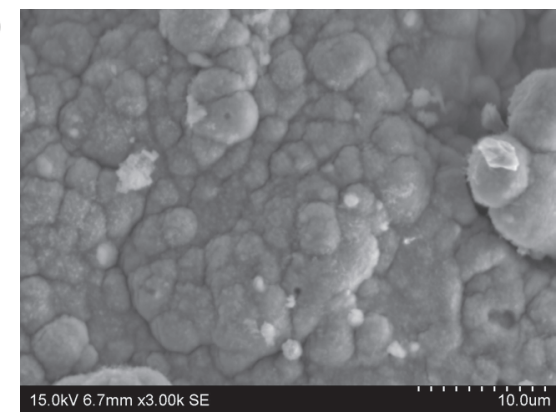

Fig. 4. The microstructure of a graphite mold with the deposited W/Zr $+D L C$ coating: a) crosssection; b) upper surface in top view (SEM)
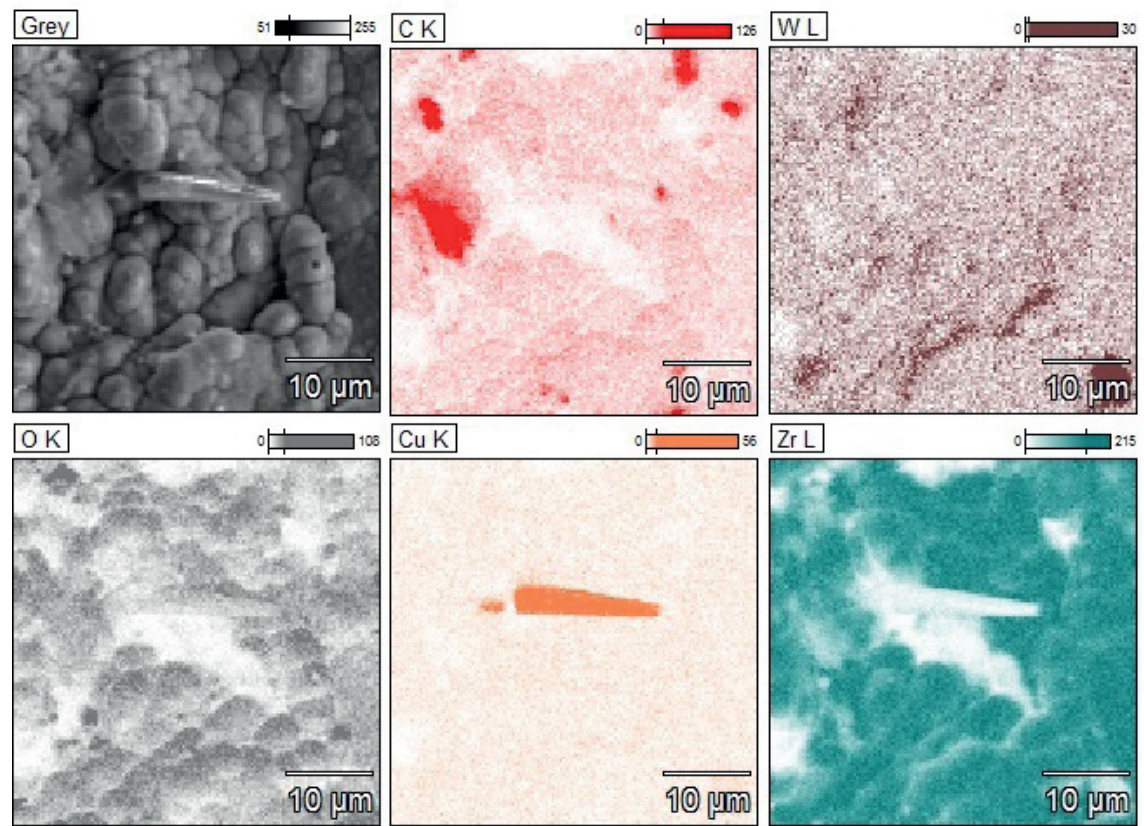

Fig. 5. Chemical analysis of a graphite mold with the deposited $W / Z r+D L C$ coating - upper surface in top view

The structure of the $\mathrm{Al}_{2} \mathrm{O}_{3}$ coating with an additional layer of glassy carbon is shown in Figure 6. The structure of the coating in the layer of $\mathrm{Al}_{2} \mathrm{O}_{3}$ contains certain discontinuities in the form of pores (dark patches) and cracks visible in the upper surface of the test material (Fig. 7). The additional layer of glassy carbon causes homogenization of the structure and (particularly through proper sealing) eliminates all pores and voids from the upper surface layer of the coating. 
a)

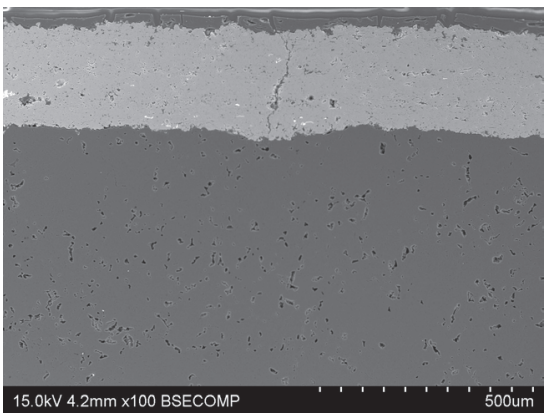

b)

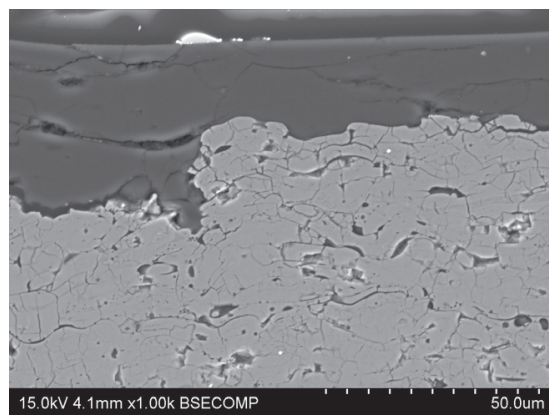

Fig. 6. The microstructure of a graphite mold with the deposited $\mathrm{Al}_{2} \mathrm{O}_{3}+$ glassy carbon coating (SEM): a) cross-section at small magnification; b) cross-section at high magnification

Examinations by scanning electron microscopy of the upper mold surface have revealed small fragments of the adhering material, which penetrated as a result of the casting process (Fig. 7). Chemical analysis has confirmed the presence in these sticking metal fragments of elements such as $\mathrm{O}, \mathrm{Al}, \mathrm{Cu}, \mathrm{Sn}$, and C, which does not change the fact that the structure in the examined mold cross-section shows no signs of the flowing medium penetrating into the coating (Fig. 6).

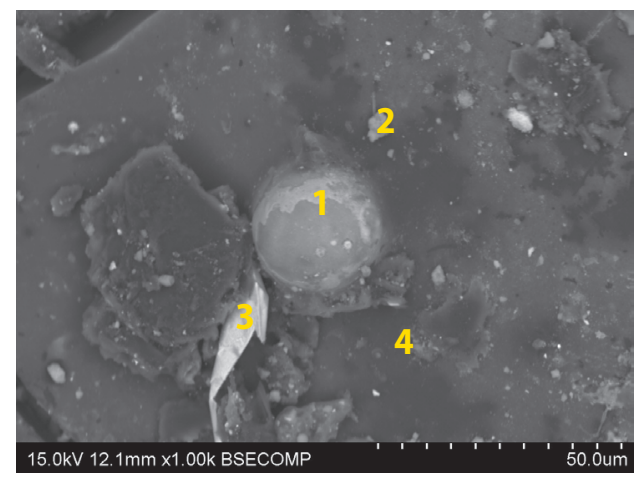

\begin{tabular}{|c|c|c|c|c|c|c|}
\hline No. & $\mathbf{C}$ & $\mathbf{0}$ & $\mathbf{A l}$ & $\mathbf{S i}$ & $\mathbf{C u}$ & Sn \\
\hline 1 & 5.17 & 65.94 & 2.07 & 26.71 & 0.11 & 0.00 \\
\hline 2 & 48.99 & 45.83 & 0.26 & 1.27 & 0.09 & 3.62 \\
\hline 3 & 10.82 & 22.80 & 10.13 & 0.08 & 55.83 & 0.35 \\
\hline 4 & 60.73 & 20.98 & 2.40 & 0.54 & 14.33 & 1.01 \\
\hline
\end{tabular}

Fig. 7. The microstructure of a graphite mold with $\mathrm{Al}_{2} \mathrm{O}_{3}+$ glassy carbon coating: upper surface in top view - chemical analysis (SEM) 
It can be concluded that the use of coatings for protecting industrial molds gives satisfactory results. Studies show that, in a mold without coating, the liquid metal penetrates into the micropores of graphite and sticks to the inner layer of the mold. In molds with coatings, the penetration of metal is avoided, and only local sticking of molten metal to the surface can occur; however, it has been found that, in coated molds, the amount of cast metal sticking to the mold surface is definitely smaller than in molds without coating.

\section{Conclusions}

- The use of protective coatings on graphite molds seems to be an effective solution.

- Stuck fragments of metal are visible inside the mold without coating.

- The W/Zr + DLC coating has good resistance during the casting process. The liquid metal sticks to the surface but does not penetrate deep inside the mold.

- The $\mathrm{Al}_{2} \mathrm{O}_{3}+$ glassy carbon coatings are also capable of protecting the graphite molds.

- The deposition of coatings reduces the downtime necessary to replace the wornout mold and increases the efficiency of the casting process.

- The type of manufacturing technology and process parameters significantly affect the microstructure and properties of the coatings.

\section{Acknowledgements}

The work was supported by project No. INNOTECH - K2/IN2/9/181851/NCBR/13.

\section{References}

[1] Walkowicz J., Smolik J., Miernik K., Bujak J.: Duplex surface treatment of moulds for pressure casting of aluminium. Surface and Coatings Technology, 97, 1 (1997), 453-464

[2] Panjan P., Čekada R., Kirn R., Soković M.: Improvement of die-casting tools with duplex treatment. Surface and Coatings Technology, 180-181 (2004), 561-565

[3] Richert M.W.: The wear resistance of thermal spray the tungsten and chromium carbides coatings. Journal of Achievements in Materials and Manufacturing Engineering, 47, 2 (2011), 177-183

[4] Fusco M.A., Ay Y., Casey A.H.M., Bourham M.A., Winfrey A.L.: Corrosion of single layer thin film protective coatings on steel substrates for high level waste containers. Progress in Nuclear Energy, 89 (2016), 159-169

[5] Richert M., Leszczyńska-Madej B., Nejman I., Zawadzka P., Pietrzyk S.: Selection of protective coatings obtained by plasma spraying method for foundry industry. Key Engineering Material, 682 (2016), 177-181

[6] Richert M., Zawadzka P.: Powłoki użytkowe na narzędziach i częściach maszyn dla przemysłu metali nieżelaznych. Obróbka Plastyczna Metali, 25, 1 (2014), 5-26 
[7] Mazurkiewicz A., Richert M., Smolik J.: Nanostrukturalne powłoki na bazie węglika chromu $\mathrm{Cr}_{3} \mathrm{C}_{2}$ wytwarzane różnymi metodami PVD. Problemy Eksploatacji, 4 (2011), 115-124

[8] Mazurkiewicz A., Smolik J.: Development of novel nano-structure functional coatings with use the original hybrid device. Material Science Forum, 674 (2011), 1-9

[9] Shanmugavelayuthan G., Kabayashi A.: Mechanical properties and oxidation behaviour of plasma sprayed functionally graded zirconia-alumina thermal barrier coatings. Material Chemistry and Physics, 103 (2007), 283-289

[10] Hegazy N., Shoeib M., Abdel-Samea S., Kader-Abdel H.: Effect of plasma sprayed alumina coating on corrosion resistance. $13^{\text {th }}$ International Conference on Aerospace Sciences \& Aviation Technology, May 26-28 2009, paper ASAT-13-MS-14, 1-10

[11] Tomaszewski H.: Węgiel szklisty - nowa postać węgla do zastosowań przemysłowych. Materiały Elektroniczne, 21,1 (1978), 27-39

[12] Richert M., Nejman I., Leszczyńska-Madej B., Zawadzka P., Smolik J.: Effect of the addition of glassy carbon on the structure and properties of $\mathrm{ZrO}_{2}-\mathrm{Y}_{2} \mathrm{O}_{3}$ coatings. Key Engineering Materials, 682 (2016), 182-188

[13] Cho T.Y., Yoon J.H., Kim K.S., Song K.O., Joo Y.K., Fang W., Zhang S.H., Youn S.J., Chun H.G., Hwang S.Y.: A study on HVOF coatings of micron and nano WC-Co powders. Surface and Coatings Technology, 202, 22-23 (2008), 5556-5559

[14] Nahvai S.M., Jafari M.: Microstructure and properties of advanced HVOF-sprayed WC-based cermet coatings. Surface and Coatings Technology, 286 (2016), 95-102

[15] Wang C.T., Escudeiro A., Polcar T., Cavalerio A., Wood R.J.K., Gao N., Langdon T.G.: Indentation and scratch testing of DLC-Zr coatings on ultrafine-grained titanium processed by high-pressure torsion. WEAR, 306, 1-2 (2013), 304-310

[16] Vitu T., Escudeiro A., Polcar T., Cavalerio A.: Sliding properties of Zr-DLC coatings: The effect of tribolayer formation. Surface and Coatings Technology, 258 (2014), 734-745 